\section{En erfaren sykepleier i lommen?}

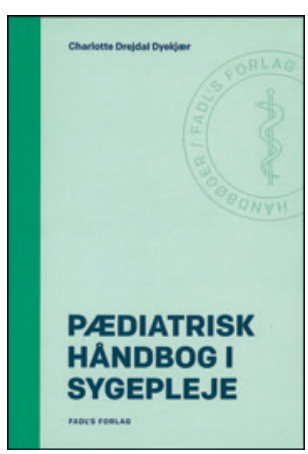

Charlotte Drejdal Dyekjær Pædiatrisk håndbog i sygepleje

84 s, tab, ill. København: FADL's Forlag, 2017.

Pris DKK 230

ISBN 978-87-7749-905-0

I Pcediatrisk håndbok i sygepleje henvender forfatteren seg hovedsakelig til sykepleiere, men også til annet helsepersonell som har interesse for arbeidet med syke barn og deres familier. Boken er liten og tynn med god passform for en kjortellomme. Det passer godt ettersom forfatterens intensjon er at helsepersonell som arbeider med barn, skal ha mulighet for å kunne ha med seg en erfaren sykepleier i lommen.

Innholdet er basert på teori og forfatterens lange kliniske erfaring som sykepleier ved en pediatrisk avdeling. Boken består av fem deler: møte med barnet og familien, det friske og det syke barnet, sykepleie til barn under innleggelse, sykepleie til kronisk syke barn og til slutt barneavdelingen nå og $\mathrm{i}$ fremtiden. Illustrasjonene er enkle og tilpasset innholdet, og tabellene er relevante og oversiktlige.

Boken er enkel å følge, og viktige poenger er uthevet med fet skrifttype. Henvisningen til teori fremstår derimot som svært tilfeldig. Teksten er basert på forfatterens lange erfaring innenfor pediatrisk sykepleie, men det oppleves uryddig når forfatteren kun velger å henvise til noe av teorien som beskrives. Når boken i tillegg inneholder direkte feil, for eksempel beskrivelse av normal finmotorikk hos et ett år gammelt barn ved at det kan tegne en person med hode og ben og klippe med saks langs en strek, så blir manglende teoretiske henvisninger ytterligere negativt. Kapittel 3 er bygd opp med beskrivelser av ulike sykdomskasuistikker med forslag til sykepleie knyttet til disse. Intensjonen er god, for forfatteren får frem ulike fremgangsmåter for aktuelle sykepleiehandlinger knyttet til vanlige diagnoser på en barneavdeling. Det er da synd at forfatteren viser mangelfulle kunnskaper knyttet til respirasjonsvurderinger, ettersom hennes tiltak i forhold til forhøyet $\mathrm{pCO} 2$ (hyperkapni) hos både barn med pneumoni og RS-virus er oksygenbehandling. Tidligere $i$ teksten har hun redegjort for hvordan man måler oksygenmetning og aktuelle referanseverdier knyttet til ulike aldre. Denne parameteren tar hun dessverre ikke med seg videre.

Intensjonen er god, men beklageligvis inneholder boken en del feil og mangler som gjør at den ikke kan fungere som det hjelpemidlet forfatteren antagelig hadde sett for seg.

Mari Oma Ohnstad

Høgskolelektor, Lovisenberg Diakonale Høgskole

\section{Kirurgiens grønne enger}

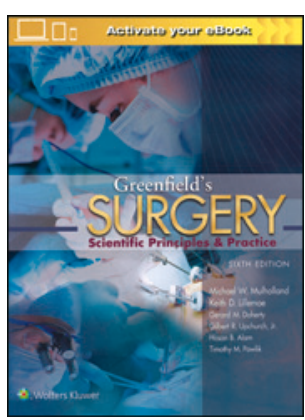

Michael W. Mulholland, Keith D. Lillemoe, Gerard M. Doherty et al, red. Greenfield's surgery

Scientific principles and practice. 6. utg. 2 127 s, tab, ill. Philadelphia, PA: Wolters Kluwer, 2017. Pris GBP 133 ISBN 978-1-4698-9001-2

I denne sjette utgaven av en kirurgisk klassiker er det opprinnelige konseptet bevart - vitenskapelige prinsipper og klinisk praksis utgjør hver sine to hoveddeler. Boken introduseres med et betimelig kapittel om «lifelong learning». I første hoveddel gjennomgås dagens forståelse av prinsipper rundt metabolisme, hemostase, inflammasjon, sjokk, anestesi og en rekke andre grunnleggende temaer. Den andre hoveddelen omhandler kirurgisk praksis fra hode til tå, begynnende med traume og transplantasjon i seksjon A og B, og avsluttende med barnekirurgi og hud og bløtvev i seksjonene $\mathrm{N}$ og O. Totalt inneholder boken 109 kapitler, og over 200 forfattere, i all hovedsak fra Nord-Amerika, har bidratt. Hvert kapittel har listet 6-10 kjernepunkter.

Den klare fordelen er at samtlige temaer som er aktuelle innen et fullstendig kirurgisk kompendium og utdanningsløp, blir gjennomgått. I tillegg er fagområder som kanskje er perifere for praktiserende kirurger, oversiktlig og pedagogisk fremstilt med kjernereferanser tydelig markert. Boken er rikt illustrert med fargetegninger, tabeller og diagrammer. Man finner over 100 algoritmer indeksert fremst, slik at man raskt kan slå opp. Innbindingen og papiret er solid, og formatet er tydelig gjennomarbeidet.

Hele boken er også tilgjengelig i nettformat og nedlastbar på smarttelefon eller nettbrett, noe som fungerer veldig fint på iPhone. Man kan i tillegg lese den på nett med muligheter for å markere og gjøre egne notater i margen, noe som gjør den til et nyttig studieverktøy. I nettutgaven er referansene klikkbare, men man sendes ikke videre til fulltekstkilde på nett, noe som enkelt kunne vært gjort for økt nytte. I papirversjonen er kjernereferansene markert tydelig, slik at interesserte kan fordype seg ytterligere.

Denne kirurgiske læreboken er rettet mot så vel medisinstudenter som praktiserende kirurger. Med sine knappe fem kilo fordelt på over 2000 sider virker den nok avskrekkende på mange, men boken har helt klart sine fordeler som en generell oversikt innen det meste av kirurgi. Jeg kan trygt anbefale den til vordende kirurger. Utdanningsavdelinger bør ha et eksemplar tilgjengelig. Med det digitale eBook-alternativet i lommen får man dobbel nytte av dette oppslagsverket som medisinstudent, utdanningskandidat eller ferdig kirurg.

\section{Kjetil Søreide}

Overlege, Gastrokirurgisk avdeling

Stavanger universitetssjukehus 